\title{
STUDI LITERATUR PENGARUH PSIKOLOGI PENDIDIKAN TERHADAP KEBERHASILAN PEMBELAJARAN
}

\author{
Nurul Rochaini \\ Program Studi Pendidikan IPA, Fakultas Keguruan dan Ilmu Pendidikan, Universitas Jember, \\ e-mail: rochaininurul@gmail.com
}

\begin{abstract}
Psychology is the science that talks about human behavior in the teaching and learning process, and it has a close relationship with teaching science. In the teaching and learning process, students are told to be able to understand and master all material taught by educators. Each student has different abilities. But the success of a learning is influenced by the psychological conditions (psychology) of their students. The purpose of this study was to find solutions to learning problems caused by the psychological conditions of students. If a student is in an uncomfortable, depressed, or fearful condition then any good learning method will not work.
\end{abstract}

Keyword: psychology, student

\section{PENDAhULUAN}

Kata psikologi berasal dari bahasa inggris psychology yang dalam istilah lama disebut ilmu jiwa. Kata pychology merupakan dua akar kata yang bersumber dari bahasa Greek (Yunani), yaitu: (1) psyche yang berarti jiwa; (2) logos yang berarti ilmu. Jadi, secara harfiyah psikologi memang berarti ilmu jiwa.

Psikologi pendidikan sebagai salah satu cabang dari psikologi dan merupakan ilmu pengetahuann yang berbicara tentang tingkah laku manusia dalam proses belajarmengajar memiliki hubungan yang erat dengan ilmu mengajar. Di mana dalam proses mengajar, para pendidik dituntut untuk memiliki pengetahuan yang memadai tentang materi yang diajarkan, dan juga menguasai berbagai metode dalam penyampaian agar apa yang disampaikan dapat dimengerti dan mudah dipahami oleh anak didik. Oleh karena itu, penguasaan terhadap ilmu jiwa pendidikan (psikologi pendidikan) juga merupakan suatu tuntutan bagi orang-orang yang bergelut dalam dunia pendidikan (Ichsan, 2016).

Pendidikan adalah salah satu topik bahasan yang menarik dan tidak ada habisnya jika dibahas. Mengingat cita-cita bangsa indonesia pada pembukaan UUD 1945 adalah "mencerdaskan kehidupan bangsa". Menurut Poerbakawatja dan Harahap dalam Muhibbin Syah (2001) pendidikan merupakan usaha secara sengaja dari orang dewasa untuk meningkatkan kedewasaan yang selalu diartikan sebagai kemampuan untuk bertanggung jawab terhadap segala perbuatannya.

Landasan psikologis pendidikan adalah suatu landasan dalam proses pendidikan yang membahas berbagai informasi tentang kehidupan manusia pada umumnya serta gejala-gejala yang berkaitan dengan aspek pribadi manusia pada setiap tahapan usia perkembangan tertentu untuk mengenali dan menyikapi manusia sesuai dengan tahapan usia perkembangannya yang bertujuan untuk memudahkan proses pendidikan. Kajian psikologi yang erat hubungannya dengan pendidikan adalah yang berkaitan dengan kecerdasan, berpikir, dan belajar (Tirtarahardja, 2005: 106).

\section{METODE PENELITIAN}

Secara sistematis langkah-langkah dalam artikel ilmiah dapat digambarkan sebagai berikut.

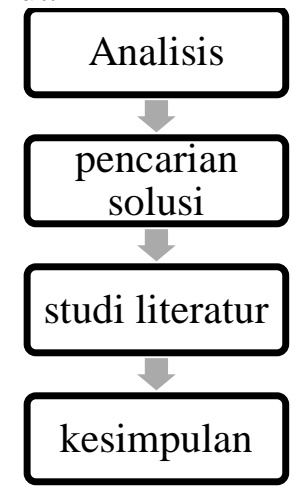

\section{ScienceEdu Vol. II. No. 2 Desember 2019}


Pertama harus melakukan analisis terhadap permasalahan yang terjadi. Menganalisis sebab dan akibat, sejauhmana permasalahan tersebut berdampak pada keberhasilan pembelajaran pada peserta didik. Kemudian mencari solusi yang dapat mengatasi masalah tersebut. Solusi dapat berupa pemikiran atau gagasan dengan berpedoman padadasar teori yang disajikan. Lalu mencari referensi dari berbagai sumber terpercaya dan relefan dengan permasalahn yang telah dianalisis. Sumber bisa diperoleh dari jurnal, buku, artikel laporan penelitian, situs-situs internet (bukan blogspot atau wordpress), dan pustaka. Tujuannya adalah memperkuat gagasan dan dasar teori. Selanjutnya menarik kesimpulan dari permasalahan dan literatur sehingga menjadi solusi yang tepat untuk mengatasi permasalahan.

\section{HASIL DAN PEMBAHASAN}

Pendidikan pada dasarnya adalah usaha sadar untuk menumbuhkembangkan potensi sumber daya manusia peserta didik dengan cara mendorong dan memfasilitasi kegiatan belajar mereka. Dalam keseluruhan proses pendidikan disekolah, kegiatan belajar merupakan kegiatan yang paling pokok.

Secara umum, keberhasilan belajar dapat diartikan sebagai suatu hasil yang dicapai setelah melakukan proses belajar. Jika diartikan menurut kosakatanya, yaitu keberhasilan dan belajar, maka dapat difahami suatu pengertian keberhasilan belajar ialah suatu hasil yang dicapai setelah melakukan aktifitas yang membawa pada perubahan individu atau suatu hasil yang dicapai setelah melakukan aktifitas belajar (Arifin, 1999: 78)

Keberhasilan pembelajaran tidak lepas dari proses pembelajaran. Proses pembelajaran bisa berhasil hanya apabila peserta didik mampu menerima materi yang disampaikan pendidik tanpa adanya suatu tekanan apapun. Kondisi psikologi peserta didik sangatlah berpengaruh karena jika terjadi tekanan yang membuat peserta didik tidak nyaman, maka fokus pikirannya bukan kepada materi yang disampaikan.
Melainkan pada permasalahan yang mengganggu fikiran dan hatinya. Bahkan ketika peserta didik kehilangan rasa percaya diri, itu juga akan berpengaruh pada semangat belajarnya. Jika peserta didik tidak kehilangan semangat belajar, mustahil apabila keberhasilan pembelajaran dapat diraih.

Sebagian besar tolak ukur kecerdasan peserta didik selain ditinjau dari IQ-nya juga dapat dilihat dari hasil belajarnya. Namun bagaiman jika seorang peserta didik mempunyai IQ di atas rata-rata tetapi hasil belajarnya kurang memuaskan? Mungkin saja faktor psikologi menjadi pemicunya. Adanya tekanan dapat membuat peserta didik hilang semangat dan sangat mempengaru terhadan kejiwaannya. Terlebih lagi jika permasalahannya sampai menggangu proses pembelajarannya.

Pakar pendidik harus paham dengan kondisi psikologi peserta didiknya. Pakar pendidik berperan besar dalam kesuksesan suatu pembelajaran. Pakar pendidik bukan hanya dituntuk untuk profesional, tapi juga dapat memahami kondisi peserta didik. Dalam berbagai kasus seringkali pendidik terlalu menekan keras pada sistem pembelajaran. Padahal hakikinya setiap peserta didik memiliki tingkat kemampuan yang berbeda-beda. Layaknya manusia pada umumnya, peserta didik juga dipandang sebagai individu-individu yang berbeda. Individu menunjukkan kedudukan peserta didik sebagai perseorangan atau persona. Oleh karena itu, sebagai sebagai orang perseorangan, peserta didik memiliki sifatsifat atau karakteristik yang menjadikannya berbeda dengan individu yang lain. Perbedaan antar peserta didik dapat disebabkan oleh dua faktor utama yaitu bawaan lahir dan pengaruh lingkungan.

Dalam dunia pendidikan, perbedaan individual peserta didik merupakan hal penting yang perlu dipertimbangkan. Segala bentuk kebijakan maupun pelaksanaan kegiatan belajar mengajar disekolah harus disesuaikan dengan karakteristik, bakat, kemampuan, kapasitas, gaya belajar, bahkan tingkat kecerdasan peserta didik. 
Hal ini sejalan dengan pendapat Yeti dkk. (2014: 72) yang menyatakan bahwa peserta didik dalam kegiatan pendidikan merupakan objek utama yang kepadanyalah segala yang berhubungan dengan aktivitas pendidikan dirujukkan

Psikologi pendidikan memberikan banyak kontribusi kepada pendidik dan calon pendidik untuk meningkatkan efisiensi proses pembelajaran pada kondisi yang berbedabeda. Berikut terdapat beberapa manfaat dalam mempelajari psikologi pendidikan:

1. Memahami Perbedaan Siswa (Diversity of Student)

Setiap individu dilahirkan dengan membawa potensi yang berbeda-beda, tidak ada yang sama antara siwa satu dengan siswa yang lainnya. Oleh karena itu, seorang guru harus memahami keberagaman antara siswa satu dengan siswa yang lainnya, mulai dari perbedaan tingkat pertumbuhannya, tugas perkembangannya sampai pada masingmasing potensi yang dimiliki oleh anak. Dengan pemahaman guru yang baik terhadap siswanya, maka bisa menciptakan hasil pembelajaran yang efektif dan efisien serta mampu menciptakan suasana pembelajaran yang kondusif.

2. Untuk Memilih Strategi dan Metode Pembelajaran

Sebagai Seorang pendidik dalam memilih strategi dan metode pembelajaran harus menyesuaikan dengan tugas perkembangan dan karakteristik masing-masing peserta didiknya. Hal ini bisa didapatkan oleh seorang guru melalui mempelajari psikologi terutama tugas-tugas perkembangan manusia. Jika metode dan model pendidikan sudah bisa menyesuaikan dengan kondisi peserta didik, maka proses pembelajaran bisa berjalan dengan maksimal.

3. Untuk menciptakan Iklim Belajar yang Kondusif di dalam Kelas

Kemampuan guru dalam menciptakan iklim dan kondisi pembelajaran yang kondusif mampu membantu proses pembelajaran berjalan secara efektif. Seorang pendidik harus mengetahui prinsip-prinsip yang tepat dalam proses belajar mengajar, pendekatan yang berbeda menyesuaikan karakteristik siswa dalam mengajar untuk menghasilkan proses belajar mengajar yang lebih baik. Disinilah peran psikologi pendidikan yang mampu mengajarkan bagaimana seorang pendidik mampu memahami kondisi psikologis dan menciptakan suasana pembelajaran yang kondusif, sehingga proses pembelajaran di dalam kelas bisa berjalan secara efektif.

4. Memberikan Bimbingan dan Pengarahan kepada Siswa

Selain berperan sebagai pengajar di dalam kelas, seorang guru juga diharapkan bisa menjadi seorang pembimbing yang mempu memberikan bimbingan kepada peserta didiknya, terutama ketika peserta didik mendapatkan permasalahan akademik. Dengan berperan sebagai seorang pembimbing seorang pendidik juga lebih bisa melakukan pendekatan secara emosional terhadap peserta didiknya. Jika sudah tercipta hubungan emosional yang positif antara pendidik dan peserta didiknya, maka proses pembelajaran juga akan tercipta secara menyenangkan.

5. Mengevaluasi Hasil Pembelajaran

Tugas utama guru/pendidik adalah mengajar di dalam kelas dan melakukan evaluasi dari hasil pengajaran yang sudah dilakukan. Dengan mempelajari psikologi pendidikan diharapkan seorang pendidik mampu memberikan penilaian dan evaluasi secara adil menyesuaikan dengan kemampuan yang dimiliki oleh masingmasing peserta didik tanpa membedakan antara satu dengan yang lainnya (Novianti, 2015)

Kecerdasan peserta didik merupakan hal yang perlu diketahui oleh pelaksana pendidikan terutama pendidik yang secara langsung mendidik peserta didik tersebut. Bagi sesama peserta didik juga perlu diketahui agar dapat bertoleransi dengan sesama peserta didik yang memiliki perbedaan karakteristik. Guru dapat memberikan contoh sikap penerimaan dan toleransi sehingga peserta didik merasa nyaman di sekolah sekaligus untuk menanamkan nilai-nilai dan bahkan menikmati perbedaan diantara mereka tanpa 
adanya rasa curiga (Law Nolte \& Harris, 2016: 137).

\section{KESIMPULAN}

Pendidik haruslah memahami jika kemampuan peserta didik memang berbedabeda. Pendidik tidak boleh menyamaratakan perlakuan terhadap peserta didik. Menyamaratakan perlakuan hanya akan membuat peserta didik yang tidak memiliki intelektual tinggi menjadi tertekan. Jika dalam kondisi tertekan maka akan berpengaruh pada saat pembelajaran sehingga hasil belajarnya juga berpengaruh. Alangkah biijaknya jika pendidik memahami setiap karakter siswanya, memperlakukan mereka sesuai dengan kemampuan yang mereka miliki. Dengan tujuan keberhasilan dalam pendidikan dapat diraih.

\section{DAFTAR PUSTAKA}

Arifin, Zainal. 1999. Evaluasi Instruksional. Bandung: PT. Remaja Rosdakarya.

Ichsan, Muhammad. 2016. Psikologi Pendidikan dan Ilmu Mengajar. JURNAL EDUKASI. 2(1): 60-76.

Muhibbinsyah. 2001. Psikologi Pendidikan dengan Pendekatan Baru. Bandung: PT. Remaja Rosdakarya.

Novianti. 2015. Peranan Psikologi Pendidikan dalam Proses Belajar Mengajar. JURNAL PENDIDIKAN DASAR. 2(2): 55-60.

Tirtarahardja, Umar dan Sulo, La. 2005. Pengantar Pendidikan. Jakarta: Rineka Cipta.
Yeti, H., \& Mumuh, M. (2014). Manajemen Sumber Daya Pendidikan.Bandung: CV Pustaka Setia. 